\title{
Applying Section 12(2) of the 1933 Securities Act to the Aftermarket
}

\author{
Adam D. Hirsh $\uparrow$
}

Consider the following situation. Oliver Offeror is a securities dealer specializing in real estate investment trusts (REITs). Investors like REITs because they are diversified portfolios of credits that yield tax benefits and an income stream. Finding himself with 250 units of last year's $\$ 30$ million REIT to resell, the "These Stores are Great Trust" (TSGT), Offeror phones Ian Investor.

Offeror tells Investor on the phone that the trust is "doing great" and is virtually a "no risk" investment. He explains that earnings per unit last year were "around $\$ 25$," that the stores and malls included in the TSGT are "spread out all over the United States," and that the local economies around each store are all very strong. Investor, though a cautious sort, has heard good things about Offeror and trusts his advice; he pays Offeror the $\$ 25,000$ asking price for the 250 units.

Unfortunately, nine months later the TSGT collapses when all of the properties default on their mortgages. Apparently Offeror had misread the earnings to Investor on the phone; they were in fact $\$ 2.50$ per unit, not $\$ 25.00$. In addition, Offeror's representation of the diversity of the stores' locations was mistaken: 52 percent of the stores were in southern Texas, where unemployment was three times the national average. Offeror would have known this had he looked at the security's original prospectus, which described the location of all the stores in the REIT.

Furious at losing $\$ 25,000$ of his hard-earned money in what he terms a "slimy securities sale," Investor meets with his lawyer, Amy Attorney, to discuss a lawsuit against Offeror. Attorney explains that it might be a difficult suit to win under the securities laws. Section 11 of the Securities Act of 1933 ("1933 Act") 1 applies only to errors in the registration statement or prospectus; because this was a sale in the secondary market, no prospectus was needed. Section $17(a)^{2}$ of the same act makes unlawful transactions involv-

$\dagger$ B.A. 1986, Yale University; J.D. Candidate 1991, The University of Chicago.

115 USC $\S 77 \mathrm{k}$ (1988). The Act begins at $\S 77 \mathrm{a}$.

215 USC $\S 77 q(a)$ (1988). For the complete text of $\S 17(a)$, see note 93. 
ing material misstatements and omissions, but many circuits do not recognize an implied private cause of action under that statute. $^{3}$

Attorney mentions that a private cause of action does exist under $\S 10(\mathrm{~b})$ of the Securities Exchange Act of 1934 ("1934 Act") and Rule 10b-5 promulgated thereunder, ${ }^{5}$ but explains that $\S 10(\mathrm{~b})$ would require Investor to prove both his reliance on Offeror's statements, and Offeror's scienter-that Offeror knew he was making material misstatements and omissions, or at least was reckless in this regard. Section 12(2) of the 1933 Act, $^{6}$ on the other hand, provides for recovery based on negligence, but many courts have held that $\S 12(2)$ only applies to initial offerings of securities. Nonetheless, Attorney explains that she thinks § 12(2) should apply to sales of securities in the secondary market, and files Investor's suit on that basis. Will Investor win his suit? Should Investor win his suit?

The preceding hypothetical is not an exam question. Rather, it demonstrates the quandary in which investors who feel defrauded in the secondary market (or "aftermarket") may find themselves." The provisions of the 1933 and 1934 Acts are complex and interrelated. Section 12 of the 1933 Act provides that:

Any person who-

(1) offers or sells a security in violation of section 5 [registration procedures], or

(2) offers or sells a security (whether or not exempted by the provisions of section 3 [delineating those classes of securities for which registration is not required], other than paragraph (2) of subsection (a) thereof [primarily government and bank securities]), by the use of any means or instruments of transportation or communication in interstate commerce or of the mails, by means of a prospectus or oral communication, which includes an untrue statement of a material fact or omits to state a material fact necessary in order to make the statements, in the light of the circumstances under which they were made, not misleading (the purchaser not knowing of

\footnotetext{
3 See text at notes $97-101$.

- 15 USC \& 78j(b) (1988). See note 104 for the complete text of $\S 10(b)$. The 1934 Act begins at $\S 78 \mathrm{a}$.

s 17 CFR $\S 240.10 \mathrm{~b}-5$ (1988). For complete text of Rule 10b-5, see note 105.

- 15 USC $\& 77 l(2)(1988)$.

7 The term "fraud" is used generically to mean an action based on false or misleading statements and omissions, regardless of the actor's intent to deceive.
} 
such untruth or omission), and who shall not sustain the burden of proof that he did not know, and in the exercise of reasonable care could not have known, of such untruth or omission, shall be liable to the person purchasing such security from him [in rescission]. ${ }^{8}$

Allowing plaintiffs to sue under $\S 12(2)$ for sales in the aftermarket would greatly increase their opportunity for redress in dubious transactions. The remedy applies to virtually all registered and unregistered securities; the plaintiff need neither plead nor prove reliance; and the defendant has the burden of proving the absence of negligence. The plaintiff's only burden is demonstrating that she did not know of the material misstatement or omission. The available remedy is rescission of the transaction, not merely an award of estimated damages. The courts have split, however, on whether $\S 12(2)$ should apply to aftermarket transactions.

Section I of this Comment explains why more exacting consideration of $\S 12(2)$ 's reach is warranted. The current case law is convoluted, and many cases rely on a false assumption that a "bright line" exists between the 1933 and 1934 Acts, whereby the 1933 Act applies only to initial distributions of securities while the 1934 Act applies only to subsequent trades. Section II analyzes the language of $\S 12(2)$ in light of its legislative history and its place in the securities law statutory scheme. It concludes that applying $\S 12(2)$ to the aftermarket is consistent both with judicial interpretation of the statute and with the securities laws. Finally, Section III approaches the problem normatively, describing the conditions under which $\S 12(2)$ ought to apply to secondary sales.

\section{The Need for a Principled Analysis}

\section{A. The Courts' Treatment of the Issue}

The current case law on this subject is, in a word, muddled. No Court of Appeals has considered whether § 12(2) applies to aftermarket transactions. The district courts that have considered the question have reached contrary results, sometimes even within the same district. ${ }^{9}$ In 1955, the federal court for the Southern Dis-

- 15 USC $\S 77 l$ (1988).

- In addition to the Southern District case discussed in the text, compare Ballay $v$ Legg Mason Wood Walker, Inc., 1988 WL 137464 (E D Pa), aff'd on other grounds, 878 F2d 729 (3d Cir 1989) (§ 12(2) applies to secondary sales), with Leonard $v$ Shearson Lehman/American Exp., Inc., 687 F Supp 177 (E D Pa 1988) (does not apply); Elysian Federal Savings v First Interregional Equity Corp., 713 F Supp 737 (D NJ 1989) (applies), with Panek $v$ 
trict of New York held in Wilko $v$ Swan that $\S 12(2)$ applies to secondary sales. ${ }^{10}$ In recent years, however, it has consistently held that $\S 12(2)$ does not apply to such transactions. ${ }^{11}$ While other district courts have relied on Wilko in holding that $\S 12(2)$ applies to the aftermarket, ${ }^{12}$ the Southern District has never cited Wilko, not even to discredit or distinguish it. ${ }^{13}$

Courts tend to discuss the $\S 12(2)$ issue in a conclusory manner, often as part of a laundry list of issues that arise on motions to dismiss or for summary judgment. ${ }^{14}$ Indeed, SSH Co., Ltd. $v$ Shearson Lehman Bros., Inc., which has been called a "seminal" decision of the Southern District on the matter, ${ }^{15}$ contains only a one-paragraph discussion of the issue that ultimately depends on a securities hornbook for the general proposition that " $[t]$ he purpose of the ' 33 Act was the regulation of the distribution of securities. Post-distribution trading is regulated by the " 34 Act."

Other courts have ignored the statute or have failed to adequately consider the larger statutory scheme. In Cheltenham Bank $v$ Drexel Burnham Lambert, Inc., the court concluded that the recent cases refusing to extend $\S 12(2)$ liability to the aftermarket were "better reason[ed]," but did not explain why. The court declared that remedies for secondary market purchasers are found in the 1934 Act, not the 1933 Act, and rejected the plaintiffs' reliance on Wilko, stating that that decision was "nearly 35 years old and,

Bogucz, 718 F Supp 1228 (D NJ 1989) (does not apply). See also Scotch v Moseley, Hallgarten, Estabrook \& Weeden Inc., 709 F Supp 95 (M D Pa 1988) (applies); Mix v E.F. Hutton $\&$ Co., 720 F Supp 8 (D DC 1989) (does not apply); First Union Brokerage u Milos, 717 F Supp 1519 (S D Fla 1989) (does not apply); and Ralph v Prudential-Bache Securities, Inc., 692 F Supp 1322 (S D Fla 1988) (does not apply).

${ }^{10} 127$ F Supp 55, 58-60 (S D NY 1955).

"See McCowan v Dean Witter Reynolds, Inc., [Current Binder] Fed Secur L Rptr (CCH) I 94,423 at 92,726-27 (S D NY), appeal dismissed, 889 F2d 451 (2d Cir 1989); Strong v Paine Webber, Inc., 700 F Supp 4 (S D.NY 1988); and SSH Co., Ltd. v Shearson Lehman Bros. Inc., 678 F Supp 1055 (S D NY 1987).

${ }^{12}$ See Ballay, 1988 WL 137464 at 12; Scotch, 709 F Supp at 97; and Elysian, 713 F Supp at 750.

${ }^{13}$ The Second Circuit has cited Wilko once, but only for the general proposition that the civil liability provisions of the 1933 Act were part of a "broad integrated program" to obtain honest dealings in securities. Superintendent of Ins. of State of N.Y. v Bankers Life \& Cas. Co., 430 F2d 355, 361 (2d Cir 1970), rev'd on other grounds, 404 US 6 (1971). 1059.

14 See Milos, 717 F Supp at 1522-23; Strong, 700 F Supp at 5; and SSH, 678 F Supp at

${ }^{15}$ Mix $v$ E.F. Hutton, 720 F Supp at 11.

${ }^{16} 678$ F Supp 1055, 1059 (S D NY 1987) (emphasis in original), citing Louis Loss, Fundamentals of Securities Regulation 92 (Little, Brown, 1983). The existence of such a "bright line" distinction between the 1933"and 1934 Acts is discussed in section IB, text at notes 27-36. 
while a decision from the same district, was not even noted by the court in [SSH]." While it is true that older cases may carry less weight than recent ones, this does not excuse the court's failure to respond to the issues raised in Wilko; any "bright line" between the 1933 and 1934 Acts that existed in 1989 would also have existed in 1955-the Acts' remedies have not changed. ${ }^{18}$

In First Union Brokerage $v$ Milos ${ }^{19}$ the court found a bright line distinction between the 1933 and 1934 Acts, relying almost exclusively on SSH. The court's only other citation on this issue was of a passage in a Supreme Court case explaining that $\S 11$ of the 1933 Act applies to registered offerings. ${ }^{20}$ It is not clear how this passage supports the Milos court's position: that one section of the Act applies to registered offerings says nothing about what other sections involve. Indeed, $\S \S 11$ and 12(2) have virtually no overlap of coverage between them. ${ }^{21}$

A third example is Ralph $v$ Prudential-Bache Securities, Inc. ${ }^{22}$ The plaintiff had asked the court to extend the Supreme Court's decision in United States $v$ Naftalin, ${ }^{23}$ holding that $\S 17(a)$ of the 1933 Act (the criminal antifraud provision) ${ }^{24}$ applies to aftermarket transactions. The Ralph court refused to do so, flatly stating that "[ $t]$ he language of section 17(a) differs from that of section 12(2),"25 but neglecting to analyze the differences in wording between the two statutes.

Despite their striking lack of analysis, $S S H$ and its progeny have, in one commentator's words, "assumed proportions as an apparently formidable body of doctrine, a circumstance that sometimes invites ongoing invocation of stare decisis rather than pause

17 [Current Binder] Fed Secur L Rptr (CCH) I 94,391 at 92,542 (E D NC 1989).

1s Also, the fact that the Southern District has never cited Wilko reduces the rationale for "reverse" stare decisis, or deviating from a precedent because another court did so. Here, the Cheltenham court relied on the Southern District's mere omission rather than any explicit discussion and rejection of a precedent, a reliance that is much more tenuous.

10 717 F Supp 1519, 1522 (S D Fla 1989).

${ }^{20}$ Id at 1522 n 7, citing Herman \& MacLean v Huddleston, 459 US 375, 381-82 (1983). Section 11 provides purchasers of registered securities a right of action against certain parties for misstatements or omissions in the registration statement of a public offering. 15 USC \& 77k (1988).

31 See text at notes $84-86$ for a more detailed discussion of the relationship between $\S \S$ 11 and 12(2).

22 692 F Supp 1322 (S D Fla 1988).

ss 441 US 768, 778 (1979).

24 15 USC $\$ 77 \mathrm{q}(\mathrm{a})$ (1988). For the complete text of $\S 17(\mathrm{a})$, see note 93 .

${ }^{2 s}$ Ralph, 692 F Supp at 1324. 
for statutory interpretation." ${ }^{28}$ A more probing examination is needed.

B. The "Bright Line" Between the 1933 and 1934 Acts

The SSH line of cases rejects $\S 12(2)$ 's applicability to the aftermarket on the grounds that the 1933 Act is concerned solely with initial distributions of securities while the 1934 Act is concerned solely with subsequent trades. Other courts, however, have recognized that the "conceptual overlap and interrelationships are less clearcut."27

The Acts contain identical savings clauses providing that "[t]he rights and remedies provided by this [chapter] shall be in addition to any and all other rights and remedies that may exist at law or in equity."28 This leaves the buyer the option of choosing the most efficacious remedy. ${ }^{29}$ The court in Elysian Federal Savings $v$ First Interregional Equity Corp. went further: "To be sure, the Securities Act contains all of the operative provisions governing new securities offerings. ... [H] owever the Securities Act may have a broader concern, i.e., to ensure full and fair disclosure concerning securities sold across state lines. There is no suggestion that the concern about full and fair disclosure is restricted to new offerings of securities across state lines. Instead, the broad language is read to apply to both new offerings and subsequent trades." 30 The Supreme Court has noted that " [ $t]$ he fact that there may well be some overlap [between the Acts] is neither unusual nor unfortunate." "\$1

The 1933 Act is in fact not concerned solely with initial distributions of securities. Section 11 of the 1933 Act provides an express civil remedy for misstatements or omissions in the registration statement of a public offering. ${ }^{32}$ A plaintiff can recover under $\S 11$ up to one year after the registration's effective date, even if

${ }^{28}$ Douglas E. Abrams, The Scope of Liability Under Section 12 of the Securities Act of 1933: "Participation" and the Pertinent Legislative Materials, 15 Fordham Urban L J 877,880 (1987) (discussing a line of cases concerning the definition of "seller" in § 12).

${ }^{27}$ Elysian, 713 F Supp at 748.

${ }^{28} 1933$ Act \& 16, 15 USC \& 77p; 1934 Act \& 28(a), 15 USC § 78bb(a).

29 Wilko, $127 \mathrm{~F}$ Supp at 59.

so 713 F Supp 737, 749 (D NJ 1989) (footnote omitted).

31 Naftalin, 441 US at 778 (citation omitted). See also Herman \& MacLean v Huddleston, 459 US 375, 382-83 (1983), in which the Court held that a plaintiff could maintain an action under $\S 10(\mathrm{~b})$ of the 1934 Act even though an action also was available under $\S 11$ of the 1933 Act.

s2 15 USC $\$ 77 \mathrm{k}$. 
she purchases the security in the secondary market. ${ }^{33}$ The relationship between $\S \S 11$ and 12(2) will be explored more closely later, ${ }^{34}$ but the important point for the moment is that it is uncontroversial that some actions can be maintained under the 1933 Act even though the securities were purchased in the open market.

Even more indicative of the breadth of the 1933 Act is the Supreme Court's extension of $\S 17$ (a) to the aftermarket in United States v Naftalin. The Court noted that the 1933 Act was "primarily concerned" with the regulation of new offerings, but that $\S 17(a)$ 's antifraud prohibition was a "major departure from that limitation" and covered any fraudulent scheme, whether in the primary or the secondary market. ${ }^{35}$ Since $\S 17$ (a) applies to all securities, whether or not registered, extending it to the aftermarket is significant because it means that any security sold at any time is potentially subject to a 1933 Act remedy. In short, Naftalin eliminated the bright line.

Even courts that have refused to extend $\S 12(2)$ to the aftermarket have agreed that it is a "civil liability analogue to $\S 17$." "36 The question, then, is whether $\S 12(2)$ also was meant as a "major departure." Since the "bright line" between the Acts is in fact invisible, we must turn to the language and legislative history of $\S 12(2)$, and its place in the overall scheme of the securities laws, to determine its reach.

\section{Section 12(2)'s Language and Place in the Statutory SCHEME}

\section{A. The Plain Language of Section 12(2)}

Section 12(2) provides for liability of "[a]ny person who ... offers or sells $a$ security . . . by means of a prospectus or oral communication ..." that contains a material misstatement or omission. ${ }^{37}$ These are words of expansion, not limitation; for example, it is difficult to imagine language broader than "any" or "a." 38 Noth-

ss See Barnes v Osofsky, 373 F2d 269 (2d Cir 1967); and Louis Loss, Fundamentals of Securities Regulation 896 (Little, Brown, 2d ed 1988). The statute of limitations provision of the 1933 Act is $\S 13,15$ USC $\$ 77 \mathrm{~m}$.

st See text at notes 84-86.

23441 US at 777-78.

36 Mix, 720 F Supp at 11 (citation omitted). The relationship between $\$ \$ 17$ (a) and $12(2)$ is explored more fully at notes $93-103$.

${ }^{37} 15$ USC $\S 77 l(2)$ (emphasis added). See text at note 8 for the complete text of $\S 12(2)$.

ss In examining two of the antifraud provisions of the 1934 Act, $\S 10$ (b) (15 USC \& 78j(b) (1988)) and Rule 10b-5 (17 CFR § 240.10b-5 (1988)), the Supreme Court noted that the words of both were "broad and, by the repeated use of the word 'any,' [were] obviously 
ing in the statutory language suggests that liability is restricted to the initial distribution of securities. ${ }^{39}$ An examination of the individual words employed supports this natural reading.

\section{1. "Offer" and "sell."}

The term "offer" is defined in the 1933 Act as including "every attempt or offer to dispose of, or solicitation of an offer to buy, a security or interest in a security, for value." ${ }^{\prime 0}$ The Act defines "sell" to include "every contract of sale or disposition of a security or interest in a security, for value." ity to think that these expansive definitions apply only to those who offer securities in an initial distribution.

In Pinter $v$ Dahl, ${ }^{42}$ the Supreme Court expounded on the meaning of "seller" in a case involving $\S 12(1)$ of the Act, and resolved a dispute among courts and commentators as to who constitutes a statutory seller. ${ }^{43}$ Noting that in "common parlance," one need not transfer title to property in order to be a seller, the Court determined that brokers who solicit purchases are "sellers" within the meaning of $\S 12(1){ }^{44}$

Since most secondary sales go through a broker or dealer, ${ }^{45}$ Pinter is important because it indicates that aftermarket transactions are not automatically excluded from the purview of the 1933 Act. If the Court had found that a broker could not be a "person who ... offers or sells a security" within the meaning of the 1933 Act, the application of $\S 12(2)$ liability to the aftermarket would have much less impact.

Although the Pinter Court expressly declined to "take a position on" the meaning of "seller" within $\S 12(2)$, it conceded that

meant to be inclusive." Affiliated Ute Citizens $v$ United States, 406 US 128, 151 (1972). See notes 104 and 105 for the full texts of these provisions. The Court used this construction to reach an expansive reading of those sections. Similarly, there appears to be no reason to limit the scope of the words when used in $\S 12(2)$.

39 See Ballay, 1988 WL 137464 at 11; Elysian, 713 F Supp at 750; and Marc I. Steinberg, The Propriety and Scope of Cumulative Remedies Under the Federal Securities Laws, 67 Cornell L Rev 557, 585 (1982).

to 1933 Act $\S 2(3), 15$ USC $\S 77 \mathrm{~b}(3)$.

11 Id.

42486 US 622 (1988).

1s See Beck v Cantor, Fitzgerald \& Co. Inc., 621 F Supp 1547, 1560-61 (N D Il 1985); Collins $v$ Signetics Corp., 605 F2d 110, 113 (3d Cir 1979); and Patricia A. O'Hara, Erosion of the Privity Requirement in Section 12(2) of the Securities Act of 1933: The Expanded Meaning of Seller, 31 UCLA L Rev 921 (1984).

4 Pinter, 486 US at 642-43, 646.

45 Brokers act as agents for other principals; dealers are brokers who can also act as principals themselves. 
the term is usually given the same meaning as in $\S 12(1) .{ }^{46}$ Indeed, the relevant language of the two sections is identical, ${ }^{47}$ and it is not surprising that all courts that have considered the question have applied the Pinter standard of "seller" to $\S 12(2) .^{48}$

\section{2. "Prospectus" and "oral communication."}

Although the term "prospectus" is defined in the 1933 Act, the term "oral communication" is not. The definition of "prospectus" includes any "communication, written or by radio or television, which offers any security for sale or confirms the sale of any security ...."49 Since a prospectus is associated exclusively with an initial offering, § 12(2)'s application to the aftermarket must rest on the term "oral communication." indication that the provision applies only to securities sold in an initial offering. Moreover, the phrase "or oral communication" in $\S 12(2)$ must add something beyond the oral communications (those by television and radio) included in the definition of "prospectus." If Congress's intention was to limit the meaning of the phrase to initial distributions, it could easily have done so by writing "by means of a prospectus or related oral communication."51 This would have made clear that the oral communications that might give rise to a $\S 12(2)$ action were those in lieu of a prospectus, thus necessarily involving an initial distribution.

The "reasonably plain meaning" of a statute creates a presumption of proper interpretation. ${ }^{62}$ Reading $\S 12(2)$ to apply to sales in the aftermarket is reasonable, but because the term "oral communication" is not defined in the Act, this reading is not compelled. Buttressing conventional interpretative principles is the language at the beginning of the definitional section of the 1933 Act: all terms are to have their defined meanings "unless the context otherwise requires."

48 Pinter, 486 US at $642 \mathrm{n} 20$.

47 See text at note 8.

4ee Craftmatic Securities Litigation v Kraftsow, 890 F2d 628, 634-36 (3d Cir 1990) (collecting cases).

41933 Act $\S 2(10), 15$ USC $\S 77 \mathrm{~b}(10)$.

so See Elysian, 713 F Supp at $750 \mathrm{n} 17$.

s1 See id at 750 (emphasis in original).

${ }^{62}$ Aaron v SEC, 446 US 680, 700 (1980). Of course, just how clear even the seemingly clearest language can be has been much discussed. Consider Max Radin, Statutory Interpretation, 43 Harv L Rev 863, 866 (1930), labeling the interpretation of words an exercise in "theological philology," and noting that even plain words are not "unambiguous."

ss 1933 Act \& 2,15 USC § 77b. 
caveat is meant to refer-the context of the particular statutory provision, or the more general context of the statutory scheme and congressional purpose. Because the context chosen may affect how broadly or narrowly the terms are construed, the next subsection explores the purpose and legislative history of $\S 12(2)$ to see if there is a "very clear expression ... of congressional intent" to negate the plain meaning of the statute. ${ }^{54}$

B. The Legislative History of Section 12(2)

1. The purpose of the 1933 Act.

The sweeping objectives of the 1933 Act support reading $\S 12(2)$ 's reference to oral communications to include the aftermarket. President Roosevelt introduced the Act in March 1933 to "give impetus to honest dealing in securities and thereby bring back public confidence" in the wake of the market crash of 1929. ${ }^{\circ 5}$ The integrated program of the 1933 Act has two parts: disclosure and remedies. Disclosure ensures that investors have the opportunity to exercise informed judgment; remedies help curb deception by imposing liability for misrepresentations. The fact that $\S \S 12(2)$ and 17(a) apply to virtually all securities, whether disclosure is required or not, indicates that the program against fraud and deception in the sale of securities is the broader of the two purposes. ${ }^{56}$ There is no indication that Congress believed only investors in initial offerings needed these protections. ${ }^{.77}$

The Supreme Court has made conflicting statements on how broad an effect these purposes should be given in interpreting the Act. On the one hand, the Court has "repeatedly recognized that securities laws combating fraud should be construed 'not technically and restrictively, but flexibly to effectuate [their] remedial

34 Aaron, 446 US at 697. Note again, though, Professor Radin's caution that legislative intent is "practically undiscoverable and ... irrelevant if discovered." Radin, 43 Harv L Rev at 875 (cited in note 52). On the pitfalls of reliance on legislative history, see also Cass R. Sunstein, Interpreting Statutes in the Regulatory State, 103 Harv L Rev 407, 429-34 (1989), and Justice Scalia's concurrence in United States v Taylor, 487 US 326, 345 (1988).

${ }^{3 s}$ Securities Act of 1933, HR Rep No 85, 73d Cong, 1st Sess 2 (1933) (message of President Roosevelt to Congress), reprinted in Federal Bar Assn Securities Law Committee (FBASLC), 1 Federal Securities Laws Legislative History 1933-1982 138-67 (BNA, 1983) ("Legislative History"),

${ }^{\mathrm{BB}}$ See Wilko, 127 F Supp at 58; and 15 USC $\$ \$ 77 l(2), 77 \mathrm{q}(\mathrm{a})$. For the complete text of $\S 12(2)$, see text at note 8; for the complete text of $\S 17(a)$, see note 93 .

${ }^{87}$ The 1934 Act, on the other hand, "was intended principally to protect investors against manipulation of stock ... prices and to impose regular reporting requirements on companies whose stock is listed on national securities exchanges." Ernst \& Ernst v Hochfelder, 425 US 185, 195 (1976) (citing S Rep No 792, 73d Cong, 2d Sess 1-5 (1934)). 
purposes." "O8 On the other hand, the Court has often found that the "broad remedial goals of the Securities Act are insufficient justification for interpreting a specific provision more broadly than its language and the statutory scheme reasonably permit." look at the specific history of $\S 12(2)$ and its place in the statutory scheme is therefore appropriate.

\section{Purposes of Section 12(2) in particular.}

As the Supreme Court has remarked, the legislative history of $\S 12(2)$ is "sparse." any special reference to the phrase "or oral communication." The primary House report describing the 1933 Act often conflated descriptions of $\S \S 11$ and 12; in fact, § 12 was never analyzed separately. ${ }^{61}$ The "essential characteristic" of the civil liability provisions, the committee wrote, was "a requirement that all those responsible for statements upon the face of which the public is solicited to invest its money shall be held to standards like those imposed by law upon a fiduciary." ${ }^{22}$ In short, the House report is filled with bravado, ${ }^{63}$ but the specifics of $\S 12(2)$ must be gleaned from the Act's theme of "let the seller also beware." has never been substantively amended by Congress. ${ }^{85}$

The Court explored this history in Pinter $v$ Dahl and offered the following line of argument: (1) the purpose of the 1933 Act was to provide investors with accurate information about securities; (2) sellers have information superior to that of buyers; (3) to force an equalization of this information asymmetry, sellers have a duty to disclose, and buyers have an action against sellers for material mis-

${ }^{88}$ Herman \& MacLean v Huddleston, 459 US 375, 386-87 (1983) (citations omitted).

39 Pinter v Dahl, 486 US 622, 653 (1988) (citations omitted).

- Randall v Loftsgaarden, 478 US 647, 657 (1986).

61 See HR Rep No 85 at 9-10, reprinted in FBASLC, 1 Legislative History at 146-47 (cited in note 55).

61 HR Rep No 85 at 5, 1 Legislative History at 142.

es For instance, the report claims that "only the dishonest man could object to the principles of the legislation ...." HR Rep No 85 at 3, 1 Legislative History at 140.

of HR Rep No 85 at 2, 1 Legislative History at 139 (message from President Roosevelt). This goal can also be seen in the shift of the burden of proof onto the defendant in actions under $\$ \$ 11$ and 12; this was seen as "indispensable to make the buyer's remedies under these sections practically effective." HR Rep No 85 at 9, 1 Legislative History at 146.

6s One non-substantive change was made in 1954, when the definition of "offer" was split out from the definition of "sell," and \$12(2) was amended accordingly to read "offers or sells." See 1954 Amendments to the Securities Act of 1933, Pub L No 83-577, 68 Stat 683, 686 , codified at 15 USC $\$ \S 77 \mathrm{~b}(3), 77 l$, reprinted in FBASLC, 1 Legislative History at 323, 326 (cited in note 55); S Rep No 1036, 83d Cong, 2d Sess 4-5, 18 (1954), reprinted in 1 Legislative History at 333-34, 347. 
statements; and (4) since solicitation is the point at which the most information is transferred, the buyer's remedy must be at its strongest there and, in fact, should be "in terrorem."

Assuming for now that sellers in the secondary market also have information superior to that of buyers, ${ }^{67}$ the Pinter rationale applies with equal force to solicitations in the aftermarket. As the Wilko court stated, it would be "absurd" for the rights of the purchaser to "depend not upon whether fraud in fact was practised but upon the status of the vendor" in the primary or secondary market. ${ }^{68}$ It may be the case that Congress was not mindful of buyers in the secondary market, but its concern with stopping sellers from making material misrepresentations was so strong that it is difficult to believe that Congress would not have wanted to protect other buyers as well.

The operation of $\S 12(2)$ demonstrates its in terrorem nature and special function as a remedial (both compensatory and deterrent) statute. Section 12(2) is the only civil remedy under the 1933 Act that applies both to registered and unregistered securities. It provides for a rescission remedy, which the Supreme Court has found to be "an additional measure of deterrence as compared to a purely compensatory measure of damages." ${ }^{69}$ Under $\S 12(2)$, a purchaser need not actually have relied on the misrepresentation or omission to recover; indeed, if the misstatements were made in writing, the plaintiff need not even have received the prospectus. ${ }^{70}$ The purchaser need only show that she did not know of the misstatement or omission - the burden of due care was intentionally "throw[n] upon" the defendant. ${ }^{21}$ Finally, § 12(2) applies to intrastate transactions as well, "even when the only use of the mails or interstate facilities is in making delivery" of the security. ${ }^{72}$ The in terrorem nature of $\S 12(2)$ suggests that it applies equally to aftermarket transactions.

${ }^{68}$ Pinter, 486 US at 646-47. Though Pinter involved § 12(1), the Court focused on the term "sells," which has the same meaning in $\S \S 12(1)$ and 12(2). See text at notes 46-48.

${ }^{67}$ This assumption will be analyzed in Section III.

es Wilko, 127 F Supp at 59. See also note 7.

${ }^{69}$ Loftsgaarden, $478 \mathrm{US}$ at 659.

${ }^{70}$ Sanders $v$ John Nuveen \& Co., Inc., 619 F2d 1222, 1225-26 (7th Cir 1980).

${ }^{71}$ Loss, Fundamentals of Securities Regulation at 889-90, 894-95 (cited in note 33); Sanders, 619 F2d at 1228-29; and HR Rep No 85 at 9, reprinted in FBASLC, 1 Legislative History at 146 (cited in note 55).

${ }^{72}$ Louis Loss, "Fraud" and Civil Liability under the Federal Securities Laws 37 (Fed Jud Ctr, 1983) (“Civil Liability"), citing Blackwell v Bentsen, 203 F2d 690 (5th Cir 1953). 
3. Comparison to Section 17(a).

Another way of testing $\S 12(2)$ 's reach is by comparing it with $\S 17(a)$, which the Supreme Court held in United States $v$ Naftalin to apply to secondary sales. The criminal provisions now contained in $\S 17$ were intended to prevent exploitation through misrepresentation, to promote adequate disclosure, and "to protect honest enterprise."

The [Securities Act] subjects the sale of old or outstanding securities to the same criminal penalties and injunctive authority for fraud, deception, or misrepresentation as in the case of new issues put out after the approval of the act. In other words, fraud or deception in the sale of securities may be prosecuted regardless of whether the security is old or new, or whether or not it is of the class of securities exempted ..... . ${ }^{74}$

The Naftalin Court relied on this passage as evidence that $\S 17$ (a) applied to secondary sales as well as to initial distributions. ${ }^{75}$

The House report on $\S 17$ (a) was more subdued, stating that the Commission "may apply to the courts to enjoin any device, scheme, or artifice to defraud, employed in connection with the sale ... of any securities, whether new or already outstanding." The Conference Report did not even mention the criminal provision in its analysis of the Act. ${ }^{77}$ As to civil liability, the House report emphasized that liability for $\S \S 11$ and 12 violations attaches when there is a material misstatement or omission in the registration statement or prospectus. ${ }^{78}$ As mentioned earlier, the committee did not mention "oral communication," despite the fact that the term was included in the House bill. ${ }^{29}$

The difference between the legislative histories of $\S \S 12(2)$ and 17(a) is, of course, the explicit mention of "outstanding securities" in the latter. Section 12(2)'s history is simply silent on this issue, neither explicitly limiting its application to initial distributions nor

${ }^{23} \mathrm{~S}$ Rep No 47, 73d Cong, Ist Sess 1 (1933), reprinted in FBASLC, 1 Legislative History at 89 (cited in note 55).

" S Rep No 47 at 4, 1 Legislative History at 92.

${ }^{38}$ Naftalin, 441 US at 778; see also Mix v E.F. Hutton \& Co., 720 F Supp 8, 12 (D DC $1989)$ (refusing to extend $\S 12(2)$ to the aftermarket).

${ }^{36}$ HR Rep No 85 at 6,1 Legislative History at 143.

${ }^{27}$ HR Conf Rep No 152, 73d Cong, 1st Sess (1933), 1 Legislative History at 252-80.

78 HR Rep No 85 at 9, 1 Legislative History at 146.

70 See $\S 512$ in HR 5480, 73d Cong, 1st Sess (May 3, 1933), 1 Legislative History at 12324. 
explicitly including outstanding securities. To say that $\S 17(a)$ 's legislative history shows that it was meant to apply to aftermarket transactions, and thus, by negative implication, that $\S 12(2)$ was not, is to apply on a large scale the expressio unius maxim, a maxim that the Supreme Court has unanimously refused to apply on a smaller scale at least once in interpreting the securities laws. ${ }^{80}$ The negative implication would be especially tenuous here, where we deal with merely the legislative histories of two statutes, rather than the language of the statutes themselves. Section 12(2)'s history is inconclusive, and thus is not enough of a congressional statement to overcome the interpretation in favor of aftermarket applicability based on the statute's plain language and its in terrorem nature.

\section{The Statutory Scheme}

The Supreme Court construes the securities acts in pari materia, as a "legislative scheme yielding persuasive sources of mutual comparison and contrast."'81 Extending the application of a statute is most acceptable when it will not upset an entire statutory scheme or render other provisions superfluous. ${ }^{82}$ Thus, $\S 12(2)$ 's relation to other remedies in the 1933 and 1934 Acts must be examined to determine the impact of applying § $12(2)$ to secondary sales. ${ }^{83}$

\section{Sections 11 and $12(1)$.}

Extending § 12(2)'s reach to the secondary market would have the least impact on $\S \S 11$ and 12(1), because they address harms very different from those addressed by $\S 12(2)$. Section 11 allows purchasers of registered securities to sue enumerated parties when false or misleading information is included in the offering's regis-

\footnotetext{
'so See Herman \& MacLean, 459 US at 387 n 23; and Radin, 43 Harv L Rev at 874 (cited in note 52), terming the canon of expressio unius "one of the most fatuously simple of logical fallacies." But see Loss, Fundamentals of Securities Regulation at 939 (cited in note 33) ("The Latin maxims resist burial.").

${ }^{31}$ Abrams, 15 Fordham Urban $\mathrm{L} \mathrm{J}$ at 879 (cited in note 26).

82 See, for example, Ernst \& Ernst v Hochfelder, 425 US 185, 210 (1976), rejecting the contention that proof of negligence would suffice for an action under $\S 10(\mathrm{~b})$ or Rule 10b-5 partially on the grounds that such an extension of liability would "nullify the effectiveness of the carefully drawn procedural restrictions" on the express civil provisions of $\$ \S 11,12(2)$ and 15 of the 1933 Act. (Section 15, 15 USC § 77o, imposes liability on anyone who "controls" any person liable under $\S \S 11$ or 12.)

ss See Touche Ross \& Co. v Redington, 442 US 560, 571 (1979); SEC v Sloan, 436 US 103, 112-14 (1978) (examining effect of a specific statute's interpretation on the larger statutory scheme).
} 
tration statement. ${ }^{84}$ While $\S 11$ applies to some aftermarket transactions, ${ }^{88}$ the defendant in a $\S 11$ action would not be the security's seller because ordinary dealers are not liable under $\S 11 .^{86}$ Additionally, $\S 11$ applies only to registered securities, while $\S 12(2)$ applies to registered and unregistered securities. In short, $\S 11$ is concerned with the accurate preparation of registration statements; $\S$ $12(2)$ is concerned with the selling process. Extending $\S 12(2)$ liability to aftermarket transactions thus would not interfere with the operation of $\S 11$.

Section 12(1) provides the remedy for violations of $\S 5,{ }^{87}$ which prohibits (1) the sale of a security during the registration period, and (2) the offer for sale of a security during this time without a statutory prospectus. Liability is virtually absolute, the only defense being that the security in question was exempt from $\S 5$. The rationale is deterrence, not restitution. ${ }^{88}$ Since $\S 12(1)$ applies solely to initial distributions, extending $\S 12(2)$ in the manner proposed would have no impact on $\S 12(1)$.

\section{Implied causes of action.}

Sections 11 and 12 of the 1933 Act expressly grant injured buyers a cause of action. Sometimes, however, courts imply a private cause of action from a statute that does not grant one explicitly. The Supreme Court has considered these implied actions several times in the context of the securities acts. ${ }^{89}$

The basic test for implying a cause of action continues to be the four-part inquiry the Court announced in a non-securities case, Cort $v$ Ash. ${ }^{90}$ The factors to be considered are: (1) whether the plaintiff is "one of the class for whose especial benefit the statute was enacted"; (2) whether there is a legislative intent, explicit or implicit, to create or to deny such a remedy; (3) whether it is consistent with the "underlying purposes of the legislative scheme to imply such a remedy"; and (4) whether the cause of action is tradi-

\$4 USC \& 77k.

ss See text at notes $32-34$.

so Loss, Fundamentals of Securities Regulation at 888 (cited in note 33). Of course, if the seller happened to be someone who signed the registration statement or was otherwise liable under \& 11, the plaintiff/purchaser would have a \& 11 action and a $\$ 12(2)$ action against that defendant. This would be merely coincidental, however.

s7 15 USC § 77e.

so Loss, Civil Liability at 35-36 (cited in note 72).

- For a summary of the Court's changing views on implied causes of action, see Loss, Fundamentals of Securities Regulation at 924-43 (cited in note 33).

- 422 US 66 (1975). 
tionally "relegated" to state law, so that it would be inappropriate to imply a right under federal law..$^{91}$ The Court has since explained that the "ultimate question [the factors seek to answer] is one of congressional intent." plying a private cause of action can be seen by examining the two implied rights most frequently discussed: $\S 17(\mathrm{a})$ of the 1933 Act and $\S 10(\mathrm{~b})$ of the 1934 Act.

a) Section 17(a) of the 1933 Act. Section 17(a) is a broad antifraud provision, ${ }^{93}$ applicable to the offer or sale of any security, registered or unregistered, including securities that are not covered by $\S 12(2) .{ }^{94}$ As discussed above, in Naftalin the Court held that $\S 17(a)$ applies to aftermarket transactions as well as to initial distributions. The Court has determined that proof of scienter, "a mental state embracing intent to deceive, manipulate, or defraud,"95 is required to prevail in a civil injunction action under $\S 17(a)(1)$ (employment of any "device, scheme, or artifice to defraud"), but is not required for similar actions under $\S 17(\mathrm{a})(2)$ (obtaining money by means of a material misstatement or omission) or $\S 17(a)(3)$ (engaging in a practice which "operates" as a fraud) ${ }^{98}$

91 Id at 78 (emphasis removed).

${ }_{92}$ Touche Ross \& Co. $v$ Redington, 442 US 560, 578 (1979), refusing to imply a private cause of action from $\S 17$ (a) of the 1934 Act (accounts and records). See also Loss, Fundamentals of Securities Regulation at 937-42 (cited in note 33).

os Section 17(a) provides:

It shall be unlawful for any person in the offer or sale of any securities by the use of any means or instruments of transportation or communication in interstate commerce or by the use of the mails, directly or indirectly-

(1) to employ any device, scheme, or artifice to defraud, or

(2) to obtain money or property by means of any untrue statement of a material fact or any omission to state a material fact necessary in order to make the statements made, in the light of the circumstances under which they were made, not misleading, or

(3) to engage in any transaction, practice, or course of business which operates or would operate as a fraud or deceit upon the purchaser.

15 USC \& 77q(a).

24 Section 12(2) exempts from its coverage those securities described in $\S 3(a)(2)$ of the 1933 Act.

${ }^{95}$ Ernst \& Ernst $v$ Hochfelder, 425 US at 193 \& $n$ 12. The Court has not determined whether recklessness suffices, but the Second, Third, Fifth, Seventh, Ninth, and DC Circuits have held that it does. Loss, Fundamentals of Securities Regulation at 781 \& nn 177-78 (cited in note 33 ) (collecting cases).

${ }^{86}$ Aaron v SEC, 446 US 680, 697 (1980). The SEC can seek a civil injunction under $\S 20(\mathrm{~b}), 15$ USC \& $77 \mathrm{t}(\mathrm{b})$. Note that under a literal reading of the section, liability under $\S \S 17(a)(2)$ and (3) appears to be strict; however, no court has interpreted the statute this way. Loss, Fundamentals of Securities Regulation at 785 (cited in note 33). 
The Court has declined to decide whether a private right of action exists under $\S 17(\mathrm{a}) .{ }^{97}$ The circuit courts are divided, but the trend seems to be against implying such a right. ${ }^{98}$ Professor Loss has opined that "[i]f anything in the 1933 Act can be stated categorically, the answer should be no" implied action under $\S 17(a) .{ }^{98} \mathrm{He}$ argues that since the 1933 Act deals exclusively with the sale of securities, and the Act contains express remedies for sales in $\S \S 11$ and 12, Congress could not have intended a private right of action for $\S 17(a) .{ }^{100}$ This view comports with that of commentators at the time of the Act's passage. ${ }^{101}$

The greatest potential for conflict is between $\S \S 12(2)$ and 17(a)(2), because both sections cover material misstatements and omissions of sellers. It is debatable which remedy a plaintiff would prefer. Under $\S 12(2)$ the plaintiff must prove materiality and ignorance of the untruth or omission; the defendant has the burden of proving absence of negligence. Under $\S 17(\mathrm{a})(2)$, on the other hand, the plaintiff might end up having to prove the entire case, including the attendant culpability. ${ }^{102}$ Assuming for the moment that plaintiffs deserve redress for misstatements made with a mental state of less than scienter, ${ }^{103}$ the comparison is between extending the existing civil remedy of $\S 12(2)$ to secondary sales, and

97 Herman \& MacLean, 459 US at 378 n 2.

93 See Loss, Fundamentals of Securities Regulation at 978 n 209 (cited in note 33); Louis Loss, Fundamentals of Securities Regulation 147 (Little, Brown, Supp 1989) (collecting cases); and Richard W. Jennings and Harold Marsh, Jr., Securities Regulation 890-92 (Foundation, 6th ed 1987) (collecting cases). The current views are as follows. For implying a right: Kirshner $v$ United States, 603 F2d 234, 241 (2d Cir 1978); and Daniel v International Brotherhood of Teamsters, 561 F2d 1223, 1245 (7th Cir 1977), rev'd on other grounds, 439 US 551 (1979). Against implying a right: Newcome $v$ Esrey, 862 F2d 1097 (4th Cir 1988) (en banc); Landry v All American Assurance Co., 688 F2d 381, 389-91 (5th Cir 1982); Shull v Dain, Kalman \& Quail, Inc., 561 F2d 152, 159 (8th Cir 1977); In re Washington Pub. Power Supply Sys. Securities Litigation, 823 F2d 1349, 1350-52 (9th Cir 1987) (en banc); and Currie v Cayman Resources Corp., 835 F2d 780, 784 (11th Cir 1988). The Second Circuit's position in favor of implying a right was openly questioned by Judge Friendly in Yoder v Orthomolecular Nutrition Inst., Inc., 751 F2d 555, 559 n 3 (2d Cir 1985).

9 Loss, Fundamentals of Securities Regulation at 977 (cited in note 33) (emphasis in original).

100 Id at 977-78.

${ }^{201}$ See William O. Douglas and George E. Bates, The Federal Securities Act of 1933, 43 Yale L J 171, 181-82 (1933).

${ }^{103}$ See Marc I. Steinberg, Section 17(a) of the Securities Act of 1933 After Naftalin and Redington, 68 Georgetown L J 163, 179 (1979). As written, § 17(a)(2) requires no culpability at all, but courts that imply a right of action might also read in a negligence standard-either to be proved by the plaintiff or disproved by the defendant-for fear of rendering § 12(2) nugatory where initial distributions are involved.

${ }^{103}$ This assumption will be tested in Section III. 
implying a private remedy from $\S 17(a)(2)$, which already applies to secondary sales.

Extending $\S 12(2)$ is the better approach. If a court were to imply a remedy under $\S 17(\mathrm{a})(2)$, it would have to invent the appropriate damage remedy, the statute of limitations, possible defenses, and determine the availability of punitive damages. The court would look to the congressionally-defined parameters of the other remedies of the 1933 Act to circumscribe this newly recognized remedy in $\S 17$, and $\S 12(2)$ would be the most appropriate place to look. In short, since $\S 12(2)$ is most akin in purpose and effect to $\S 17(a)$, it makes more sense to extend a remedy for which Congress has already defined the contours than to imply a new one.

b) Section 10(b) of the 1934 Act and Rule 10b-5. Section 10(b) of the 1934 Act $^{104}$ and Rule $10 \mathrm{~b}-5^{105}$ promulgated thereunder are "catchall" provisions that provide penalties for parties who engage in fraudulent schemes. ${ }^{106}$ Their purpose is primarily deterrence, not compensation. ${ }^{107}$ Four important distinctions exist between Rule 10b-5 and $\S 12(2){ }^{108}$ First, 10b-5 applies to buyers and sellers; $\S 12(2)$ applies only to sellers. Second, $10 \mathrm{~b}-5$ requires reli-

${ }^{104}$ Section 10(b) provides that:

It shall be unlawful for any person, directly or indirectly, by the use of any means or instrumentality of interstate commerce or of the mails, or of any facility of any national securities exchange-

(b) To use or employ, in connection with the purchase or sale of any security ..., any manipulative or deceptive device or contrivance in contravention of such rules and regulations as the Commission may prescribe as necessary or appropriate in the public interest or for the protection of investors.

15 USC § 78j(b) (1988).

${ }^{105}$ Rule 10b-5 provides:

It shall be unlawful for any person, directly or indirectly, by the use of any means or instrumentality of interstate commerce, or of the mails or of any facility of any national securities exchange,

(1) To employ any device, scheme, or artifice to defraud,

(2) To make any untrue statement of a material fact or to omit to state a material fact necessary in order to make the statements made, in the light of the circumstances under which they were made, not misleading, or

(3) To engage in any act, practice, or course of business which operates or would operate as a fraud or deceit upon any person,

in connection with the purchase or sale of any security.

17 CFR § 240.10b-5 (1988).

${ }^{108}$ Herman \& MacLean, 459 US at 382.

${ }^{107}$ Loss, Fundamentals of Securities Litigation at 956 (cited in note 33).

108 For a fuller discussion, see Martin I. Kaminsky, An Analysis of Securities Litigation under Section 12(2) and How it Compares with Rule 10b-5, 13 Houston L Rev 231 (1976). 
ance; ${ }^{109} \S 12(2)$ does not. Third, 10b-5 does not apply to offers; $\S 12(2)$ does. And most importantly, 10b-5 requires scienter; ${ }^{111}$ $\S 12(2)$ only requires negligence.

Neither $\S 10(\mathrm{~b})$ nor Rule $10 \mathrm{~b}-5$ by its terms creates an express private remedy for its violation, and "there is no indication that Congress, or the [SEC] . . . contemplated such a remedy . . . ."112 Nevertheless, courts began implying a private cause of action in $1946,{ }^{113}$ and the Supreme Court first approved this construction in a footnote in $1971 .^{114}$ In 1983 the Court stated flatly that the existence of the implied cause of action was "simply beyond peradventure,"115 and by 1988 the Court was heralding it as "an essential tool for enforcement of the 1934 Act's requirements." "116

The contours of a Rule 10b-5 action have changed over time, as courts have endeavored to work out a comprehensible solution. The justices have lamented:

[W]e deal with a judicial oak which has grown from little more than a legislative acorn. Such growth may be quite consistent with the congressional enactment and with the role of the federal judiciary in interpreting it, . . . but it would be disingenuous to suggest that either Congress in 1934 or the [SEC] in 1942 foreordained the present state of the law with respect to Rule $10 \mathrm{~b}-5 .{ }^{117}$

The contours remain in flux. It is still unsettled, for instance, whether a rescission remedy exists under $\S 10(b) .{ }^{118}$ Such uncertainty in interpretation may keep legal commentators very busy,

109 But see the discussion at text accompanying notes $136-39$ for the "fraud on the market" theory's relaxation of this requirement.

130 Blue Chip Stamps v Manor Drug Stores, 421 US 723 (1975).

11 Hochfelder, 425 US at 212. Although the Supreme Court has reserved the question of whether recklessness suffices in lieu of scienter (id at 193-94 $\mathrm{n} \mathrm{12}$ ), nearly all circuits have found that it does. Disagreement persists, however, as to the definition of "recklessness." See Jennings \& Marsh, Securities Regulation at 956 (cited in note 98).

112 Hochfelder, 425 US at 196 (footnotes omitted).

11 Kardon v National Gypsum Co., 69 F Supp 512 (E D Pa 1946).

114 Superintendent of Ins. of State of N.Y. v Bankers Life \& Cas. Co., 404 US 6, 13 n 9 (1971) ("It is now established that a private right of action is implied under $\S 10(\mathrm{~b})$.").

11 Herman \& MacLean, 459 US at 380.

116 Basic Inc. $v$ Levinson, 485 US 224, 230-31 (1988) (6-0 decision on this point).

117 Blue Chip Stamps, 421 US at 737.

118 See Randall $v$ Loftsgaarden, 478 US 647, 661 (1986). Some commentators consider damage calculations under Rule 10b-5 "still in a formative state," even though the cause of action has been implied for nearly 45 years. Jennings \& Marsh, Securities Regulation at 1384 (cited in note 98). 
but it produces little guidance for those who must structure their daily actions around the potential liability.

In Ernst \& Ernst $v$ Hochfelder, ${ }^{119}$ the Court held that defendant's negligence was not sufficient for 10b-5 liability. Part of the Court's rationale was that the express provisions of the securities acts that were based on negligence- $\$ \S 11$ and $12(2)$ of the 1933 Act-had "significant procedural restrictions" not applicable under $\S 10(\mathrm{~b})$ and Rule 10b-5. ${ }^{120}$ These restrictions include the posting of a bond, assessing costs, and a short statute of limitations. ${ }^{121}$ This rationale supports the application of the express provision of § 12(2)-with its procedural restrictions-to secondary sales.

Section 10(b) was meant to deter insiders from manipulating the market; $\S 12(2)$ was intended to provide purchasers a remedy against sellers for making material misstatements or omissions. The distinction in purposes is important. ${ }^{122}$ To the extent that extending $\S 12(2)$ to secondary sales would mean some overlap with actions currently litigated under $\S 10(\mathrm{~b})$, it seems clear that plaintiff purchasers would always choose $\S 12(2)$ (as long as they could satisfy the procedural restrictions) because they would not have to prove scienter or reliance. But what is wrong with this possibility? It is more straightforward to extend an express remedy-where Congress has already considered the protection potential investors deserve in offers or sales-to other situations that satisfy its specific purpose, than for courts to continually attempt to trim and manage their "judicial oak."

In sum, the Supreme Court has rejected the idea that extending a 1933 Act remedy to the aftermarket is always inappropriate, and has approved of the overlap between the Acts as being " "neither unusual nor unfortunate." "123 The Court has also implicitly approved the tradeoff between a lower intent requirement and

${ }^{138} 425$ US 185 (1976).

${ }^{120}$ Id at 208-10. The Court's other rationale was that Rule $10 \mathrm{~b}-5$ derived its standard of culpability from $\S 10(\mathrm{~b})$, which clearly required scienter. Id at 199, 201, 212-14. This rationale is irrelevant in the context of $\S 12(2)$, because $\S 12(2)$ expressly invokes a negligence standard.

${ }^{121}$ The statute of limitations applicable to $\S \S 11$ and 12(2) extends only one year after the misstatement was or should have been discovered; and, for $\S 12(2)$, in no event more than three years after the offer or sale. 1933 Act $\S 13,15$ USC $\$ 77 \mathrm{~m}$. Since Rule $10 \mathrm{~b}-5$ is an implied remedy, no statute of limitations exists in the 1934 Act; courts tend to apply whatever limit is imposed by the forum state, which is almost always longer than one year. Hochfelder, 425 US at $210 \mathrm{n} 29$.

${ }^{222}$ See Herman \& MacLean, 459 US at 382-83 (fact of overlap in coverage is irrelevant if the two causes of action address "different types of wrongdoing").

${ }^{123}$ Naftalin, 441 US at 778 (citations omitted). 
higher procedural restrictions. ${ }^{124}$ Extending $\S 12(2)$ to aftermarket transactions would not disrupt the carefully laid statutory scheme of the securities laws. Courts should recognize that it is better to extend an express remedy to like situations than to distort an implied remedy in an attempt to achieve a similar result.

\section{Narrowing Section 12(2)'s Reach in the Secondary MARKETS}

The foregoing sections have shown that applying $\S 12(2)$ to aftermarket transactions would be consistent with the language, legislative history, and judicial interpretation of the statutory scheme. Normatively, however, applying $\S 12(2)$ to every transaction involving a seller's negligent material misstatement or omission may not be the optimal approach. This section argues that while it would be inappropriate for courts to selectively apply $\S 12(2)$ 's express statutory remedy, Congress should amend $\S 12(2)$ to apply only to those aftermarket transactions where the market for the security is not efficient. ${ }^{125}$

\section{A. Asymmetric Information}

Information is essential to any market; it helps ensure that scarce capital will be applied where it will be most effective, enhancing allocative efficiency. "A world with fraud, or without adequate truthful information, is a world with too little investment, and in the wrong things to boot." ${ }^{126}$ Mandating disclosure of information helps investors make informed decisions by bringing "into the full glare of publicity those elements of real and unreal values which may lie behind a security."127 Increasing the flow of information, moreover, promotes market confidence by raising the integrity of the securities industry; investments rise when investors per-

124 Hochfelder, 425 US at 208-11.

123 One might ask why Congress has not amended $\$ 12(2)$ already. I suggest it lacks not just the time, but the incentive. As long as the courts are willing to thrash out some remedy, Congress may not feel compelled to act one way or the other. Note that Congress has never explicitly granted a private right of action under $\S 10(\mathrm{~b})$ or Rule $10 \mathrm{~b}-5$, though it is surely aware that courts have been applying such a remedy for nearly 45 years.

136 Frank H. Easterbrook and Daniel R. Fischel, Mandatory Disclosure and the Protection of Investors, $70 \mathrm{Va} \mathrm{L}$ Rev 669, 673 (1984).

127 HR Rep No 85 at 4, reprinted in FBASLC, 1 Legislative History at 141 (cited in note 55). See also William E. Van Valkenberg, Corporate Disclosure Under the Securities Act of 1933 and the Securities Exchange Act of 1934: A Historical Perspective ("Corporate Disclosure"), in Report of the Advisory Committee on Corporate Disclosure to the SEC, 95th Cong, 1st Sess 556 (HR Comm Print 95-29, 1977). 
ceive the market to be fair. But information is costly; thus, a legal system should encourage the party that can produce information at the lowest cost to do so. It is for these reasons that Congress sought, through the Securities Acts, to correct the asymmetry of information between sellers and buyers. ${ }^{128}$

The asymmetry of information is greatest when a security is first offered; the issuer must provide buyers with enough information to inform them of the quality of the new security. The 1933 Act attempts to curb the risk of capital misallocation that this asymmetry creates by requiring the issuer of a registered offering of securities to make specific statutory disclosures in a prospectus about its operations and the projects to be financed. ${ }^{129}$ Those involved in the offering are held to the standard of a fiduciary. ${ }^{130}$ Sections 11 and 12(1) allow purchasers to enforce this fiduciary relationship by expressly granting a right of action for ineffective disclosure in the registration process. The value of an accurate registration statement, however, would be lost if salespeople could mislead buyers on the "front line"; section 12(2) fills this gap by holding sellers to a fiduciary duty as well. And in the case of a nonregistered offering, ${ }^{131}$ if disclosure is required at all, it is much less than is included in a statutory prospectus. ${ }^{132}$ Since by definition the offering is not registered, the remedies of $\S \S 11$ and 12(1) are not available. Thus, $\S 12(2)$ is the only 1933 Act remedy to ensure that buyers of unregistered securities are not misled..$^{133}$

But the risk of capital misallocation does not pass with issuance and sale on the primary market, because the primary market competes for capital with the aftermarket, where the asymmetry of information can be just as pronounced. Consider Ian Investor in the hypothetical at the beginning of this Comment: it is doubtful that he knew much about the workings of an obscure REIT. And even if Oliver Offeror did not knowingly mislead Investor, the ef-

\footnotetext{
${ }^{128}$ It is debatable, of course, whether a mandatory disclosure system was necessary to correct this asymmetry. On this point, compare Easterbrook and Fischel, $70 \mathrm{Va} \mathrm{L} \mathrm{Rev} 669$ (cited in note 126), with John C. Coffee, Jr., Market Failure and the Economic Case for a Mandatory Disclosure System, 70 Va L Rev 717 (1984).

1281933 Act $\$ \$ 5,7,15$ USC $\$ \S 77 \mathrm{e}, 77 \mathrm{~g}$.

${ }^{230}$ HR Rep 85 at 5, reprinted in FBASLC, 1 Legislative History at 142 (cited in note 55).

${ }^{131}$ Sections 3 and 4 of the Securities Act, 15 USC $\S \S 77 \mathrm{c}, 77 \mathrm{~d}$, provide issuers with various exemptions from registration.

${ }^{132}$ For a summary of exempted offerings, see Jennings \& Marsh, Securities Regulation at 293-395 (cited in note 98 ).

139 This assumes that the jurisdiction does not recognize an implied private right of action under $\S 17(a)$. See text at notes 93-103.
} 
fect on Investor was the same. Yet Investor would have no redress against Offeror because he would be unable to prove scienter under Rule 10b-5. The rationale underlying $\S 12(2)$ 's application to initial distributions of securities-eliminating the asymmetry of information-is just as powerful in such a case.

At other times, however, the asymmetry of information in the aftermarket is less than in the primary market. To help ensure that the market's evaluation of outstanding securities fairly reflects their value, certain issuers are required to make ongoing disclosures while their securities are in the secondary market. ${ }^{134}$ If the issuer is obligated to make periodic disclosures, the potential investor can read these disclosures or seek assistance from a professional securities analyst. Also, there is generally not a concerted selling effort-which may lead to inflated claims - in the secondary market similar to that accompanying the distribution of a new security. ${ }^{135}$

Where we expect less asymmetry of information in the secondary market, the rationale for extending $\S 12(2)$ has less force. In an efficient market, even if individual investors are misinformed, by hypothesis the bulk of the market is not. If a broker negligently misstates IBM's 1989 earnings in an attempt to sell some shares, the potential investor does not need $\S 12(2)$ for protection because sufficient protection is provided by the market price of the stock. ${ }^{136}$

134 See Van Valkenberg, Corporate Disclosure at 573-83 (cited in note 127); and the 1934 Act $\S \S 12,13,16,15$ USC $\S \S 781,78 \mathrm{~m}, 78 \mathrm{p}$. The system of disclosure in the secondary market was left incomplete in 1934, however. The non-exchange markets (known as the "over the counter" (OTC) markets) were not even included in the disclosure system until 1964. Van Valkenberg, Corporate Disclosure at 577-83. The level of OTC trading has increased over time. In 1985, OTC trading accounted for approximately 37 percent of the 56 billion shares of common stock traded. Jennings \& Marsh, Securities Regulation at 7 (cited in note 98).

125 Van Valkenberg, Corporate Disclosure at 575 (cited in note 127). Distrust of highpressure sales efforts was one of Congress's concerns when it passed the Securities Act in 1933. See HR Rep No 85 at 2, reprinted in FBASLC, 1 Legislative History at 139 (cited in note 55).

136 This is an example of the "fraud on the market" theory. The theory is based on the hypothesis that an efficient market incorporates all public information accurately into a security's price. A misstatement or omission is material only if it misleads the entire market and thus alters the security's price. See Daniel R. Fischel, Use of Modern Finance Theory in Securities Fraud Cases Involving Actively Traded Securities, 38 Bus Law 1, 4 (1982). See also Daniel R. Fischel, Efficient Capital Markets, The Crash, and the Fraud on the Market Theory, 74 Cornell L Rev 907 (1989); Note, Fraud-on-the-Market Theory after Basic Inc. v. Levinson, 74 Cornell L Rev 964 (1989); and Barbara Black, Fraud on the Market: A Criticism of Dispensing with Reliance Requirements in Certain Open Market Transactions, 62 NC L Rev 435 (1984). A version of the theory was adopted by a plurality of the Court, three justices not participating, in Basic Inc. v Levinson, 485 US 224 (1988). 
Similarly, for debt instruments in an efficient market, the interest rate will accurately reflect the risk involved.

This Comment proposes, therefore, that $\S 12(2)$ liability should exist for sales in the secondary market when the asymmetry of information parallels the asymmetry of an initial distribution of securities, which is generally not considered to be an efficient market. ${ }^{137}$ Thus, $\S 12(2)$ should apply in inefficient secondary markets, but not in efficient ones. Determining which markets are efficient is easier said than done, however. Even Professor Fischel, one of the most ardent supporters of the fraud on the market theory, concedes that "no clear answer exists" for determining when a market is efficient. ${ }^{138}$ Relevant factors include "whether the security is listed on a national exchange, whether it is actively traded, and whether it is followed by analysts and other market professionals." ${ }^{139}$

Until Congress, a court, or a commentator devises a more exact method for determining whether a market is efficient, the SEC's definition of those issuers that may use Form S-3 for disclosure provides a useful approximation. ${ }^{140}$ The current test for qualifying for Form S-3 is satisfaction of either (1) a three-year reporting history under the 1934 Act and a "non-affiliate float" (the value of voting stock held by non-affiliates) of at least $\$ 150$ million; or (2) a non-affiliate float of at least $\$ 100$ million, and annual trading volume of at least three million shares. Approximately 30 percent of all securities on the three national exchanges (NYSE,

\footnotetext{
${ }^{237}$ But see Shores $v$ Sklar, 647 F2d 462, 470-71 (5th Cir 1981) (en banc) (initial distribution of bonds was an efficient market). For criticism of Shores, see Fischel, 38 Bus Law at 11-12 (cited in note 136); Note, 74 Cornell L Rev at 982-87 (cited in note 136); and Ross v Bank South, N.A., 885 F2d 723, 732-33 (11th Cir 1989) (en banc) (Tjoflat concurring).

Also note that some initial distributions are made on efficient markets. If General Motors were to issue new shares of common stock, they certainly would be distributed on an efficient market and would be priced at the prevailing market rate for the millions of shares already outstanding. In such a case, there would hardly be the kind of asymmetric information envisioned here for initial distributions. This explains why some of the largest companies can avoid full-blown disclosure in initial distributions by qualifying with the SEC for shelf registration. For a general explanation of shelf registration, see Jennings \& Marsh, Securities Regulation at 198-209 (cited in note 98). To the extent an issuer qualifies for shelf registration, the justification for applying $\S 12(2)$ in even an initial distribution is weakened.

${ }^{138}$ Fischel, 74 Cornell $L$ Rev at 912 (cited in note 136).

139 Id.

${ }^{140}$ See SEC Release No 6383 (March 3, 1982), excerpted in Jennings \& Marsh, Securities Regulation at 119 (cited in note 98). Form S-3 allows widely-followed corporations to integrate their 1933 and 1934 Act filings so that they do not have to disclose as much information.
} 
AMEX, and NASDAQ) qualify to use Form S-3, ${ }^{141}$ and should be deemed to be traded on efficient markets. Section 12(2) should therefore be inapplicable to secondary sales of such securities.

Limiting $\S 12(2)$ 's application to non-efficient aftermarkets best fulfills the purpose of the Securities Acts. Investors are protected by holding sellers to a high level of responsibility, and allocative efficiency is enhanced by increasing the flow of accurate information, thereby reducing information asymmetry in inefficient markets.

\section{B. Criticism and Response}

1. Overdeterrence and inefficiency.

One possible criticism of applying $\S 12(2)$ to the aftermarket is that, through overdeterrence, it will actually lead to a decrease in information. A negligence standard is inherently ambiguous. People will obviously differ on how the "exercise of reasonable care"142 would have affected the material misstatement or omission at issue. On the margin, bad things may occur: some non-negligent behavior may be erroneously found negligent (which sellers fear), and some negligent behavior may be erroneously excused (which society fears). Sellers may fear mistaken liability so much that they choose to avoid the possibility of liability by providing less information overall. Thus, the argument concludes, allocative efficiency is actually hurt by a negligence standard in the aftermarket because as the standard of liability decreases, so does the amount of information provided by sellers.

But this criticism proves too much. The proposed extension of $\S 12(2)$ would simply take a remedy that already applies to initial distributions and apply it to the aftermarket; the criticism attacks the negligence standard as a whole, not only its application to aftermarket transactions. Indeed, the rationale offered in the previous section explains not only why the negligence standard currently exists in the primary market, but also why it should apply to some cases in the aftermarket. There is a point at which saying something wrong costs more than saying nothing at all. If the negligent statement does more harm than good, it should be deterred. The information asymmetry is so great in an initial distribution that any benefit from the negligent statements of the seller (in that

\footnotetext{
141 SEC, Executive Summary of Securities Act Release Nos 6331-6338 (Aug 6, 1981), excerpted in Jennings \& Marsh, Securities Regulation at 117 (cited in note 98).

14ะ 1933 Act $\S 12(2), 15$ USC $\S 77 l(2)$.
} 
the seller may truly believe he is not negligent) is outweighed by the risk of capital misallocation. The same possibility also exists in the aftermarket, and only when we are sure that the risk of capital misallocation does not outweigh-that is, in efficient markets-should we relax the negligence standard. ${ }^{143}$

To the extent the negligence standard will chill sellers from making material statements at all, $\S 12(2)$ 's prohibition on "omit[ting] to state a material fact necessary in order to make the statements, in the light of the circumstances under which they were made, not misleading"144 comes into play. Omissions are trickier than misstatements. When is remaining silent misleading? Why should it be punished rather than rewarded? Some would argue that in a privity situation (which $\S 12(2)$ is), there is no duty on one party to disclose information to the other; indeed, the argument continues, it would be inefficient to require the party to do so. ${ }^{145}$ If a person need not disclose what is wrong with a car before she sells it, why must she be forced to do so when selling a security?

The brief answer to this criticism is that-rightly or wrongly-one of the purposes of the Securities Acts was to replace the harsh regime of caveat emptor with a system in which the seller must also beware. Congress may simply have decided that securities were more important than cars. But there is a more satisfying justification, which addresses the efficiency argument directly.

Society should encourage those that can produce information at the cheapest cost to do so, and should discourage duplicative searches for information. Professor Anthony Kronman has advocated rewarding "deliberate" searches for information by conveying a property right in that information; information obtained "casually," however, would receive no such protection. Thus, according to Kronman, a party can be required to disclose casually obtained information, but not information deliberately obtained..$^{146}$

143 Note that the Federal Securities Code proposed by the American Law Institute would impose a negligence standard on all sales in the initial and secondary markets, regardless of whether or not the market was efficient. ALI Fed Sec Code $\S \S 1602,1703(\mathrm{a})$, (b), (f) (1980).

1441933 Act $\S 12(2), 15$ USC $\S 77 l(2)$.

145 The argument may apply equally to non-privity situations, but is easier to see in a two-party transaction.

${ }_{148}$ See Anthony T. Kronman, Mistake, Disclosure, Information, and the Law of Contracts, $7 \mathrm{~J}$ Legal Stud 1, 13-14 (1978). Although the article focuses on unilateral mistake in contract law, it has important implications for securities markets as well. For critiques of Kronman, see Jules L. Coleman, Douglas D. Heckathorn, and Steven M. Maser, A Bargain- 
If, at the time of the sale, the seller has information that the buyer does not, the seller is clearly the cheapest provider of the information at that moment. Any subsequent investment of resources by the buyer is a loss to society because that investment generates no new information, but merely duplicates information the seller already possesses. Professor Kronman argues that the market never reaches this situation because the seller, knowing that he will have to disclose his information at the time of sale, will never invest resources to obtain the information in the first place. Denying a property right in information extinguishes the incentive to deliberately search for it, resulting in less information and allocative inefficiency. ${ }^{147}$ In the context of the hypothetical at the beginning of this Comment, Offeror would have no incentive to search for information about the stores in Texas if he were unable to use that information to his advantage.

But the hypothetical also demonstrates why Kronman's thesis does not prevent the extension of $\S 12(2)$ liability to the aftermarket. ${ }^{148}$ The crucial distinction is not between deliberately and casually acquired information, but between the societal and distributive consequences of the information. ${ }^{149}$ Information brought to the market increases allocative efficiency if it generates new knowledge about a good. A gem found in a box of costume jewelry reallocates capital because society now knows that there is another gem in existence. If the buyer knows the true value of the gem but the seller does not, the gem will stay misallocated unless the buyer can take advantage of his information by buying the gem at the costume price. ${ }^{180} \mathrm{It}$ is irrelevant whether the buyer obtained his information deliberately or casually.

The other component of information is the private gain, or distributive aspect. In the gem example, the buyer's private gain equals the social gain because the buyer appropriates the entire change in value from costume jewelry to gem. We want to en-

ing Theory Approach to Default Provisions and Disclosure Rules in Contract Law, 12 Harv J L \& Pub Pol 637 (1989); and Robert L. Birmingham, The Duty to Disclose and the Prisoner's Dilemma: Laidlow v. Organ, 29 Wm \& Mary L Rev 249 (1988).

117 Kronman, $7 \mathrm{~J}$ Legal Stud at 13, 16 (cited in note 146).

14 I borrow here from the articles critical of Kronman's theory cited in note 146. My argument is only that Professor Kronman is not convincing in his insistence that a system of required disclosure is necessarily of no value, not that a system of disclosure is compelled. 140 Coleman, Heckathorn, and Maser, 12 Harv J L \& Pub Pol at 694 (cited in note 146); Birmingham, $29 \mathrm{Wm} \&$ Mary L Rev at 272 (cited in note 146).

180 Consider the case of one Mr. Westine, who was able to purchase a "rock" for $\$ 10$ that he knew to be a sapphire in the rough worth $\$ 2.5$ million. \$10 Purchase of Star Sapphire Produces a New Texas Hero, NY Times A15, col 3 (Nov 17, 1986). 
courage the investment in information only up to the last dollar of societal gain from the information. If the distributive gain exceeds the societal gain, the individual will overinvest in information. For example, if Offeror finds out the stores in Texas are about to default a day before they actually do, he has the opportunity to make a large gain by not disclosing this information to Investor. Society, however, will find out the next day anyway (when the stores actually default). Offeror's gain dwarfs society's, and his information need not be rewarded. He can be made to disclose his information without any loss of efficiency.

\section{Subsidizing folly.}

Another possible criticism of $\S 12(2)$ 's application in the aftermarket is that it would encourage unsophisticated investors to invest in inefficient markets. It may be argued that decreasing the standard of culpability to negligence approaches a scheme of investors' insurance, allowing rescission of transactions that simply proved to be poor investments. Investors, the argument goes, should diversify their portfolios through devices such as mutual funds, thereby taking advantage of securities professionals who can analyze markets more cheaply and efficiently. ${ }^{151}$

The criticism is unjustified for several reasons. First, it may not even be appropriate for individuals to diversify their securities portfolio; rather, they should diversify their overall portfolio of investments. ${ }^{152}$ Under this hypothesis, investors will search out individual securities with a certain risk level or return to balance out their personal portfolio. The legal rules should therefore encourage this by protecting purchasers from being misled in inefficient secondary markets.

Second, the proposed rule of extending $\S 12(2)$ liability to inefficient secondary markets might actually result in more diversified portfolios. If sellers are aware that they will be held to the standard of a fiduciary in the aftermarket, they will be less likely to offer risky securities to unsophisticated investors. The less sophisticated the buyer, the more that could go "wrong" from the seller's standpoint. When denied the opportunity to invest in inefficient markets, unsophisticated investors will turn to efficient ones instead. Sellers can then devote their attention to buyers who already know something about the security on the inefficient market,

\footnotetext{
151 See Easterbrook \& Fischel, 70 Va L Rev at 689, 695 (cited in note 126).

182 See Coffee, $70 \mathrm{Va} \mathrm{L} \mathrm{Rev} \mathrm{at} \mathrm{748-50} \mathrm{(cited} \mathrm{in} \mathrm{note} \mathrm{128).}$
} 
and who will devote the proper amount of resources to learning more.

Of course, this argument assumes that sellers of securities can distinguish between sophisticated and unsophisticated buyers. If they cannot (and buyers have no incentive to avoid purchasing securities-cum-insurance), then their activities may be chilled and sales to all buyers may be decreased. This concern, however, is overstated. The seller should certainly be able to distinguish between the widow-and-orphan set and affluent businesspeople. The more difficult case may be the third-year associate at a law firm: he may be a sophisticated lawyer, but know nothing about securities in general or a specific security or market in particular. At the margin it is unclear what will happen; the seller may decide to deal with the buyer or not. The existence of a prior relationship between the two would certainly be a factor. ${ }^{153}$ If a seller erroneously labels as "unsophisticated" a buyer who really does know something about the security on the inefficient market, presumably the buyer could convey that information to the seller and correct the mislabeling. It must also be remembered that this is only a threshold issue-liability attaches for negligent misstatements or omissions in the sale, not for negligently choosing to deal with a particular buyer.

A third response recognizes that allowing buyers to invest in securities that turn out to be worthless impugns the overall credibility of the securities markets, and will lead to a subsequent misallocation of resources. ${ }^{154}$ Buyers will devalue all securities if they feel they cannot trust the information received from sellers. This argument depends only on the effect on the investor, not on whether the seller acted with scienter; thus, there is no special harm associated with making negligent misstatements or omissions a cause of action for buyers in the aftermarket.

Finally, an objection based on the inefficient behavior of individual investors is theoretically indeterminate; as an empirical matter, many such investors do buy individual securities. This fact may do more to undermine the concept of an efficient market (which is premised on everyone acting rationally) than to support

\footnotetext{
${ }^{15 s}$ The extent to which a negligence standard would discourage "cold" calls from brokers to potential buyers is another consequence left unanswered, objectively and normatively.

${ }^{164}$ Birmingham, $29 \mathrm{Wm}$ \& Mary L Rev at 269 (cited in note 146). Professor Birmingham's argument here is a variation of the familiar "lemons market" theory. See George A. Akerlof, The Market For "Lemons": Qualitative Uncertainty and the Market Mechanism, 84 Q J Econ 488 (1970).
} 
an argument against protecting misled investors. On the other hand, maybe they are rational actors in a system that irrationally provides incentives for them to act in socially inefficient ways. In any event, extending $\S 12(2)$ liability to aftermarket sales in inefficient markets will reduce information asymmetries; societal welfare will be enhanced because all investors will make better investment decisions.

\section{CONCLUSION}

Section 12(2) of the Securities Act of 1933 is a powerful weapon available to purchasers of securities for material misstatements or omissions negligently made by sellers. Many courts mistakenly believe that simply because the remedy appears in the 1933 Act, its application is necessarily limited to sales of securities in an initial distribution and cannot be applied to aftermarket transactions. This bright line distinction between the coverage of the 1933 and 1934 Acts is undercut, however, by a Supreme Court case holding that the 1933 Act's criminal counterpart to § 12(2) applies equally to the primary and secondary markets.

An examination of $\S 12(2)$ 's language, legislative history, and place in the statutory scheme (as interpreted by the courts) reveals that it does apply to aftermarket transactions. The plain language opposes any hint of a limitation to initial distribution, and the legislative history does not compel the opposite conclusion. Furthermore, extending $\S 12(2)$ to the aftermarket with its parameters already in place does less violence to the statutory scheme than does tinkering with implied causes of action, the route some courts prefer.

While extending § 12(2)'s application wholesale to aftermarket transactions is possible, it is not normatively optimal. The rationale underlying the remedy is appropriate in aftermarket transactions that involve an asymmetry of information analogous to the situation in an initial offering. Applying the remedy to other situations, however, would lead to a misallocation of capital by overdeterring valuable information in the marketplace. The distinction turns on whether the market is efficient or not: $\S 12(2)$ should be applied to aftermarket sales on inefficient markets, but should not be applied on efficient ones. This will ensure that negligent misstatements and omissions are deterred to the proper extent, enhancing allocative efficiency in the securities markets. 